\title{
Optymalizacja metod detekcji mutacji w genie Nud indukowanej przez technologię CRISPR/Cas9 w jęczmieniu zwyczajnym (Hordeum vulgare L.)
}

\author{
Optimization of mutation detection methods in the NUD gene induced by CRISPR / \\ CAS9 technology in barley (Hordeum vulgare L.)
}

\section{Mateusz Przyborowski ${ }^{1 凶}$, Sebastian Gasparis ${ }^{1}$, Wacław Orczyk ${ }^{2}$, Anna Nadolska-Orczyk ${ }^{1}$}

\author{
${ }^{1}$ Zakład Genomiki Funkcjonalnej, ${ }^{2}$ Zakład inżynierii Genetycznej \\ Instytut Hodowli i Aklimatyzacji Roślin — Państwowy Instytut Badawczy, Radzików \\ 凶e-mail: m.przyborowski@ihar.edu.pl
}

\begin{abstract}
Celem pracy był wybór optymalnej metody detekcji mutacji w genie Nud indukowanej z wykorzystaniem technologii CRISPR/Cas9 w jęczmieniu zwyczajnym. Testowano cztery powszechnie wykorzystywane techniki genotypowania: polimorfizm długości fragmentów restrykcyjnych (RFLP), trawienie enzymatyczne przy użyciu endonukleazy I $\mathrm{z}$ bakteriofaga T7, wysokorozdzielczą krzywą topnienia produktu reakcji łańcuchowej polimerazy (HRM-PCR) oraz sondy molekularne. W toku prowadzonych prac stwierdzono, że najkorzystniejszym sposobem wykrywania mutacji indukowanej techniką CRISPR/Cas9 jest metoda oparta o sondy molekularne. Daje ona jednoznaczne i powtarzalne wyniki ale jednocześnie wymaga użycia zawansowanej aparatury.
\end{abstract}

Słowa kluczowe: CRISPR / Cas9, edytowanie genomu, gen Nud, jęczmień zwyczajny, sondy molekularne

\begin{abstract}
The aim of the study was to select the optimal method for mutation detection in the Nud gene induced by using the CRISPR / Cas9 technology in barley. Four commonly used genotyping techniques were tested: restriction fragment length polymorphism (RFLP), enzymatic digestion using endonuclease I from T7 bacteriophage, high resolution melting curve of polymerase chain reaction product (HRM-PCR) and molecular probes. Findings in the current study suggest that the most favorable way for detecting mutations induced by the CRISPR / Cas9 technique is a method based on molecular probes. It enables to receive clear and repeatable results but at the same time requires the use of advanced equipment.
\end{abstract}

Key words: CRISPR / Cas9, genome editing, Nud gene, barley, molecular probes

CRISPR/Cas9 jest jedną z biotechnologicznych technik edytowania genomu wykorzystywaną w strategii polegającej na inaktywacji genu poprzez indukcję mutacji, a w efekcie końcowym na zahamowaniu powstawania funkcjonalnego białka kodowanego przez badany gen.

W celu wyboru optymalnej metody detekcji mutacji w genie Nud indukowanej $\mathrm{z}$ wykorzystaniem technologii CRISPR/Cas9 w jęczmieniu zwyczajnym testowano cztery powszechnie wykorzystywane techniki genotypowania: polimorfizm długości fragmentów restrykcyjnych (RFLP), trawienie enzymatyczne przy użyciu endonukleazy I z bakteriofaga T7, wysokorozdzielczą krzywą topnienia produktu reakcji łańcuchowej polimerazy (HRM-PCR) oraz sondy molekularne.

W celu ostatecznego potwierdzenia oraz określenia rodzaju mutacji wykonano sekwencjono- wanie metodą Sangera. $\mathrm{Z}$ każdej rośliny $\mathrm{T}_{0}$ sekwencjonowano co najmniej 5 klonów bakteryjnych zawierających amplikon genu $\mathrm{Nud}$.

Najkorzystniejszą techniką wykrywania mutacji indukowanej technologią CRISPR/Cas9 jest metoda oparta o sondy molekularne. Daje ona jednoznaczne i powtarzalne wyniki ale jednocześnie wymaga użycia zawansowanej aparatury. Do metod o wysokiej przepustowości oraz wymagających tylko podstawowej aparatury laboratoryjnej należą techniki wykorzystujące enzymy restrykcyjne (technika RFLP) oraz endonukleazę I z bakteriofaga T7. Najtrudniejszą technicznie, a zarazem najbardziej problematyczną $\mathrm{w}$ interpretacji wyników okazała się wysokorozdzielcza krzywa topnienia produktu reakcji łańcuchowej polimerazy (HRM-PCR).

$\underline{\text { Sponsorzy konferencji Dzień Młodego Naukowca } 2018}$

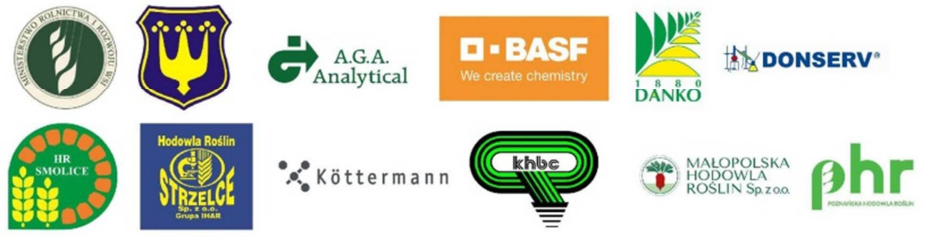


